\title{
Playing and learning in another language: ensuring good quality early years education in a language revitalisation programme
}

\begin{abstract}
Offering Gaelic medium preschool provision poses particular challenges as most children only encounter Gaelic in the playroom and live in a context heavily dominated by English. Nevertheless, expanding provision for early years education in Gaelic is an important part of ambitious plans to revitalise the language. In this paper we explore the challenges experienced by adults and children as they strive to provide good quality preschool education through the medium of Gaelic. Drawing on evidence from a review of Gaelic medium preschool education, we consider the difficulties experienced in developing a Gaelic-only immersion playroom, the need for specific resources and the perceived training needs of practitioners. We look at the issues which arise from the largely English language home learning environment and the specific pedagogical challenges experienced when supporting language learning and access to the national curriculum. Our analysis will be relevant to others working in similar cultural-linguistic and political contexts across Europe.
\end{abstract}

\section{Résumé}

À l'inverse de l'anglais, le gaélique n'est la langue d'enseignement que d'un petit nombre d'écoles maternelles en Écosse même si son but est de contribuer à son renouveau et d'enrayer sa disparition. Le développement de dispositions en faveur de l'éducation maternelle est une partie importante des projets ambitieux du gouvernement écossais afin d'augmenter considérablement le nombre d'élèves dans les écoles gaéliques d'ici à 2021. Néanmoins, cela lance des défis particuliers puisque la plupart des enfants ne sont exposés au gaélique qu'à l'école maternelle: en dehors de celle-ci, ils se trouvent dans un contexte fortement dominé par l'anglais. Dans cet article, nous explorons les défis auxquels sont confrontés les enfants et les adultes qui s'évertuent à pourvoir une éducation préscolaire en gaélique de bonne qualité. S'inspirant de résultats d'une revue d'éducation préscolaire en gaélique, nous considérons les difficultés rencontrées lors de la mise en place d'une classe d'immersion linguistique uniquement en gaélique, le manque de ressources pédagogiques spécifiques et les besoins en formation professionnelle des éducateurs. Nous examinons les questions posées par un environnement familial dans lequel l'anglais reste largement majoritaire, les défis pédagogiques spécifiques rencontrés lors du soutien pédagogique et l'accès au programme national d'enseignement. Notre analyse pourra s'avérer pertinente à ceux qui opèrent dans des contextes culturo-linguistiques et politiques semblables à travers l'Europe.

\section{Zusammenfassung}

Gälischsprachige Angebote an Einrichtungen frühkindlicher Bildung und Erziehung gehen mit spezifischen Herausforderungen einher, da die meisten dort betreuten Kinder das Gälische nur dort erleben und ansonsten in einer stark vom Englischen dominierten Umgebung aufwachsen. Nichtdestotrotz stellt der Ausbau dieses Sektors eine wichtige Komponente ehrgeiziger Pläne zur Revitalisierung der Sprache dar. In dem vorliegenden Artikel widmen wir uns den Schwierigkeiten, mit 
denen sich Erwachsene und Kinder im Rahmen anspruchsvoller pädagogischer Betreuung auf Gälisch in Spielgruppen und Krippen/Kindergärten/Kindertagesstätten konfrontiert sehen. In Auswertung einer systematischen Untersuchung frühkindlicher Tagesbetreuung auf Gälisch geht es um Schwierigkeiten bei der Ausgestaltung von Spielzimmern, in denen Kinder durchgehend auf Gälisch betreut werden (Immersionsmethode), um den Bedarf an spezifischen Lehrmitteln und anderen Materialien und um die für erforderlich gehaltene Ausbildung der Erziehenden. Desweiteren befassen wir uns mit Problemen, die sich aus dem überwiegend englischsprachigen Bildungskontext der Elterhäuser ergeben, und mit den besonderen pädagogischen Herausforderungen von Bildungssituationen, in denen sowohl Sprache gelehrt als auch der landesweit verbindliche Lehrplan (National Curriculum) vermittelt wird. Unsere Analyse dürfte für all jene von Interesse sein, die in vergleichbaren sprachlich-kulturellen und politischen Kontexten tätig sind.

\section{Resumen}

Con el objetivo de revitalizar la posición del gaélico, algunos centros escoceses de educación infantil utilizan este idioma en vías de extinción, en lugar del inglés, como medio de enseñanza. La expansión de la educación preescolar en gaélico juega un importante papel en los ambiciosos planes del gobierno escocés para incrementar considerablemente el número de niños en escuelas gaélicas antes del año 2021. Sin embargo, este programa presenta desafíos particulares, ya que la mayoría de los niños encuentran el gaélico solamente en el aula: fuera, viven en un contexto abrumadoramente dominado por el inglés. En este artículo hablamos de los desafíos experimentados por los adultos y los niños que se esfuerzan en desarrollar una educación preescolar de alta calidad en gaélico. Nuestras evidencias, basadas en una revisión de la educación preescolar en gaélico, consideran las dificultades experimentadas en desarrollar un aula de inmersión gaélica, la falta de recursos pedagógicos específicos al idioma y las necesidades de formación profesional de los educadores. Examinamos las cuestiones presentadas por un ambiente de aprendizaje casero en el cual el idioma es, en gran parte, el inglés; y además los desafíos pedagógicos experimentados por los educadores que no sólo tienen que apoyar el aprendizaje del gaélico sino también el acceso al programa de estudios nacional. Por lo tanto, nuestro análisis será útil para todos aquellos que trabajen en contextos culturales, lingüísticos y políticos similares en cualquier parte de Europa.

\section{Key words}

Gaelic medium preschool provision; immersion experience; language learning and early years curriculum; pedagogy for language learning; practitioner professional development 


\section{Playing and learning in another language: ensuring good quality early years education in a language revitalisation programme}

\section{Introduction}

The purpose of this paper is to explore the challenges involved in providing good quality preschool education in Scotland through the medium of Gaelic. The context in which Gaelic medium (GM) early years provision is offered in Scotland makes particular demands on the adults and children involved. Practitioners are challenged to nurture and sustain the linguistic development of the small number of children who enter preschool having learned Gaelic at home and to help the much larger number of children who come from English-speaking homes to learn Gaelic. At the same time they have a responsibility to ensure that all children have rich and positive learning experiences across the curriculum. Our analysis of the challenges experienced in Gaelic medium preschool identifies generic issues about pedagogy and practice that will arise in settings in cultural-linguistic and political contexts where preschool provision has a dual role as a site for learning and using a language spoken by a minority of the population and as a provider of good quality early years education.

Educational provision in Gaelic is seen by the Scottish Government and Bòrd na Gàidhlig (the public body charged with supporting the development of Gaelic) as having a critical role to play in revitalising the language and halting the drift away from Gaelic (Scottish Parliament, 2005; Bòrd na Gàidhlig, 2007a). The number of people speaking Gaelic in Scotland has been in decline for over one hundred years, falling from about $7 \%$ of the population in 1891 to $1.2 \%$ in 2001 . In the period 2004 05 under $1 \%$ of families with young children reported using Gaelic at home (SEED, 2007). The National Gaelic Education Strategy (Bòrd na Gàidhlig, 2007b) is a key part of the National Plan for Gaelic and includes ambitious plans to increase the number of children enrolled in Gaelic medium education. The strategy recognises the importance of preschool education as means of increasing access to the language for the majority of the population and seeks to increase the numbers of children beginning their education in GM settings and continuing through GM primary and secondary schooling. However, responsibility for implementing the strategy for preschool education was left to individual local authorities and to associated voluntary sector organisations. In the public sector Gaelic medium provision is usually offered by local authorities in response to local demand but there is no legal obligation to make educational services available in Gaelic.

In this paper we draw on evidence gathered during a review of Gaelic medium provision for preschool children. The review was commissioned by the Scottish Government and Bòrd na Gàidhlig to investigate whether the supply of Gaelic medium provision matches demand and to identify gaps and weaknesses in provision and the quality of the children's experiences. Our review (Stephen et al, 2010) extended to the day care offered by childminders, holiday schemes and afterschool care but in this paper we will draw only on the data as it relates to educational provision for children aged 3- to 5-years old. All children in Scotland are entitled to government-funded part-time education in the two years before they begin school. This entitlement may be taken in public sector nurseries or nursery classes or approved voluntary sector playgroups or private sector nurseries. All settings 
offering government funded places are expected to offer provision that meets the expectations of the national curriculum (Scottish Executive, 2004).

The review process is introduced below, followed by a summary of the key findings about the structural features of provision and the additional support sought to enhance GM preschool. However, the focus of this paper is on the challenges for practice and pedagogy. We will draw on our survey findings for evidence about the structural characteristics of GM preschool provision and the context in which the settings operate but when describing and discussing the playroom experiences of children and practitioners we will supplement this data with rich qualitative evidence from our three case study settings and key informant interviews.

\section{The review of Gaelic medium early years education and childcare}

The aim of the review was to describe existing provision for Gaelic-medium preschool education and to explore changes or developments needed to ensure progress towards the relevant goals of the National Gaelic Education Strategy. There were four particular areas of concern:

1 mapping current Gaelic medium provision for early years education and childcare in formal and informal settings and in the public, private and voluntary sectors

2 investigating the match between supply and demand and ways in which GM provision was promotion to parents

3 articulating the perceptions of providers and key informants about the strengths and weaknesses of current GM provision

4 articulating the changes perceived as necessary to allow GM preschool provision to meet expectations.

The research design utilised both quantitative and qualitative methods in four overlapping phases. We began by mapping provision through an extensive search of websites, local authority information services and other sources of information about early years services. The second phase was a survey of the providers identified in the mapping exercise. The providers identified were asked to complete a survey (available in Gaelic and English, on-line and in hard copy) which asked questions about the nature of provision, demand and numbers attending, marketing, costs, income and staffing and the way that Gaelic is used in the setting. Initially 43 complete surveys were returned but a further 24 were added when we contacted non-respondents by telephone, raising the rate of return from $34 \%$ to $53 \%$. Follow up telephone calls indicated that there were two hard- to-reach groups among the nonrespondents (i) childminders who were listed as being able to offer Gaelic-medium provision typically had only very limited capacity for this and were not interested in completing the survey and (ii) it was difficult to find someone to respond on behalf of small, informal groups meeting in community facilities and run by a volunteers.

In phase 3 we supplemented the setting-level information with interviews with 19 key informants, ranging from representatives of the regulatory and inspection authorities to local Gaelic Development Officers and representatives of national Gaelic organisations. This range of informants allowed us to gather perspectives about both national strategies and expectations and local, situated experiences. Our fourth 
phase consisted of three case studies of Gaelic medium provision. The aim was to exemplify and contextualise issues emerging from the survey and interviews. The cases studied provided opportunities to gather the perspectives of providers, parents and local authority representatives about Gaelic medium opportunities in a specific area and to explore further the factors which facilitate or inhibit good practice. The three locations selected were chosen to represent the range of very different contexts in which Gaelic medium education can be found: an island community where Gaelic is widely spoken; a small, northern town and a southern city, both locations where Gaelic is not widely spoken.

\section{Gaelic Medium Preschool Provision: Supply, structural features and areas for development}

The review identified 127 providers of Gaelic medium early years education or childcare, most of whom were located in the two geographical areas most strongly associated with the use of the language but there was some provision in 12 other local authority areas. In most cases provision took the form of a nursery school or class associated with a primary school. The Gaelic medium provision often ran alongside English medium preschool classes, sharing the same buildings and management structure. While there were some Gaelic medium playgroups (managed by a voluntary committee of parents) which offered government-funded places there was very little private sector Gaelic medium provision and a dearth of options for parents seeking Gaelic medium day care. Outside urban areas the number of children in any one setting was usually small and the pool of qualified practitioners is limited.

There was little evidence of the burgeoning demand for GM preschool anticipated in the National Plan. Most providers did not anticipate a growth in demand and few had plans to expand their provision. Families were typically recruited by word of mouth although other local means were used. The review recommended that there be a nationwide survey of parents to explore the nature of any un-met demand for Gaelic provision, the development of a national promotion strategy and the active involvement of national bodies in raising awareness of the benefits and availability of Gaelic medium early years provision

When asked what would improve their services two areas for dominated the responses of providers. The first was the difficulty of recruiting and retaining well qualified staff and the lack of accessible and relevant continuing professional development opportunities. The second area for development was the limited supply of Gaelic medium resources, a problem which would only be helped in part by increased funding. Providers asked for support with training, opportunities for networking and the establishment of an umbrella body to promote the interests of Gaelic medium preschool provision. Local support varied from authority to authority but few providers had any contact with local or national bodies or the support of a development worker and contact with other providers was scant, particularly in the predominantly scattered and remote areas where much of the Gaelic medium provision is located.

The literature on the impact of early education suggests that it depends on the quality of the provision and learning opportunities offered to children (e.g. Peisner- 
Feinberg and Burchinal, 1997; National Institute of Child Health and Human Development (NICHD), 2005; Sammons et al, 2004). In our review we were not able to use a measure of the quality of children's experiences such as the Early Childhood Environment Rating Scale (Harms, Cilfford and Cryer, 2004). However, we were able to collect survey data on a number of structural features that have been found to be positively associated with good quality environments for children (e.g. Goelman et al, 2006; Phillipsen et al, 1997). These features include the level of staff education and qualifications, wages, staff turnover rate, amount of non-contact time and training and professional development opportunities. The results of our survey demonstrated that practitioners in Gaelic medium settings did not have good opportunities for training and professional development, wages were not high (most frequently between $£ 6$ and $£ 12$ per hour), the rate of staff turnover was considerable in some settings and not all practitioners had non-contact time for planning and recording. These findings indicate that there is a need to improve the conditions in which practitioners work and develop their practice if children attending Gaelic medium provision are to be assured of high quality early years experiences.

\section{Establishing an effective environment for early years education and Gaelic language learning}

\section{Developing a Gaelic-only immersion playroom}

There is widespread recognition of the value of immersion models as an effective means of developing a high level of competence in a second language while supporting the maintenance of the first language (Johnson \& Swain, 1997; Baker, 2006). However, the status of English as a 'world language' means that there is very limited experience of adopting this approach in the UK, little awareness of the specific skills required of practitioners and a lack of training focused on immersion education for young learners or approaches to bilingual education in the early years more generally. Furthermore, when offered as part of a language revitalisation strategy the immersion model encounters particular issues.

Our survey suggests that while about half of the respondents wanted training in supporting language learning there was very little professional development specifically targeted at staff in Gaelic medium provision. As a result practitioners have largely had to work out for themselves how to support children's acquisition of Gaelic. The Head of the City nursery case study gave an account of her approach to second language learning and the strategies she had developed: for example using gesture and other visual clues to support children's understanding, and systematic planning to ensure linguistic progression over time.

When I first became involved with this nursery, I just saw sand as sandbut now I see it as a language learning opportunity. . . .

When I first arrived, children were learning Gaelic in a random way. I felt this had to be more focused. We decide what aspects of language we are targeting that week - might be prepositions, colours, numbers - and then we think about how can use learning experiences for this. So, for example, we might make jelly and use this as a way of talking about colours and other sensory experiences. (Head, City Nursery) 
This head teacher was able to draw on her extensive experience of reflective practice and training in planning for early years learning, as well as the support of a local authority-funded Gaelic language development officer. However, these personal and externally provided resources are not available to all practitioners, particularly those working in scattered and remote communities. There is an urgent need to synthesise the body of experience that is available on immersion education for preschool children and to find ways of dissemination and training that fit with local circumstances.

The efficacy of the immersion playroom will depend on the richness of the linguistic environment it offers (Baker, 2006; Howard et al 2005). About half of the survey respondents wanted to recruit more fluent Gaelic speakers to the staff team and $60 \%$ wanted training to improve the way in which they supported the use of Gaelic (while only $40 \%$ felt the need for additional early years practice training). This apparent lack of confidence in the linguistic environment they offered was given explicit voice in the doubts expressed by our key informants about the breadth and depth of children's exposure to Gaelic.

In nurseries, Gaelic use is not always spontaneous - richness may be lacking. For example, practitioners often feel that health and safety issues or the comforting of distressed children needs to be done through English. (Key informant A)

In some of the island nurseries, children may be fluent in Gaelic when they come in, but here, at the playgroup and the nursery, the vast majority are just taught Gaelic words. (Key informant B)

We need to add richness and breadth, particularly for children learning through Gaelic. (Local authority quality improvement officer)

The ways in which practitioners use the target language for routine situations, offer clues to understanding and build a supportive environment make an important contribution to second language learning (Mhic Mhathúna, 1999, 2008). At one setting in our island case the lead practitioner had worked hard to ensure that Gaelic was used with repetition and visual clues to reinforce meaning during routine care activities (for example, when applying sun-screen to all children before they went outside to play) and when children were engaged in learning across the curriculum. It was noticeable in this nursery that other younger and less experienced members of staff replicated this approach with the children, using Gaelic at all times - not just for specific language oriented activities but for the routine events of the day - using simple, clear language. For instance, we observed Gaelic being used throughout a memory game designed to support language and communication skills and during practitioner-led conversations that extended children's thinking about the consequences of actions. This extensive use of Gaelic contrasted with some other playrooms we visited, where staff spoke quietly, so that often their Gaelic interactions with children were not audible over the general hubbub of activity; where they shifted into English when something required quick action (e.g. to avoid an accident, or simply to get things cleared up quickly); and where they sometimes talked among themselves in English, despite being native speakers of Gaelic. 
Opportunities to link language development to other areas of early years development, such as creative and aesthetic experiences, are likely to be particularly valuable but do depend on context and availability. At the City case nursery, practitioners were able to draw on a range of Gaelic speakers and cultural experiences associated with Gaelic: they invited Gaelic storytellers to the nursery, took children to traditional music festivals, and brought Gaelic-speaking musicians to the nursery. They took part in an arts initiative to support young children's linguistic development (in this case in Gaelic) through music, drawing on funding and support from their associated Gaelic medium primary school. However, access to such a wealth of experiences is unusual and not characteristic of the rural and scattered communities where much of the Gaelic provision is situated.

One further factor limits the richness of the Gaelic-only immersion experience: the ubiquitous presence of English. Even if all the practitioners in a particular setting are fluent Gaelic speakers it is very likely that children will encounter conversations with support staff, visitors, specialist teachers and parents that are carried on in English, particularly in settings were the Gaelic medium provision is part of a larger nursery or primary school with English medium provision. Shared dining rooms and playgrounds, such as those at the City case nursery, inevitably led to a shift to English on the part of practitioners and children. Our observations suggested that, even in immersion settings, conversations between children were often in English as few of the children had learned Gaelic as their first language at home. English came more readily and allowed a more sophisticated (and possibly more effective) use of language for communication with peers.

[Preschool] only has children for a limited time and with limited language using possibilities. The language used between children who are learning Gaelic in [preschool] settings is likely to be English. (Key informant C)

The fragile Gaelic-only environment and the coherent peer culture which practitioners seek to create is further challenged when children can begin attending the setting at several different points during the year or when some attend less frequently than others (perhaps for two rather than five sessions per week).

The question of appropriate provision for the very small number of children who are already fluent in Gaelic when they begin attending nursery requires attention. These children might be expected to flourish in a linguistically rich environment but it is not clear whether their language development needs are well-catered for in provision aimed principally at learners of the language, and recent work in Wales (Hickey \& Lewis, 2009) and Ireland (Mhic Mhathúna \& Mac Con lomaire, forthcoming) indicates that this group of learners need further consideration.

\section{Resourcing a Gaelic medium playroom}

Identifying and acquiring appropriate resources was a major concern and source of frustration across providers. About two-thirds of the respondents to our survey included acquiring more Gaelic medium resources among their hopes for the future. The number and range of books published in Gaelic is limited and there is an even more restricted supply of other resources such as posters, DVDs, computer games and 'Big Books' (large format books for use with groups of children). Because many 
settings do not have access to the internet in the playroom they cannot take advantage of the resources emerging on Gaelic language websites.

Resources for prefives are limited. . . We have to go to websites to find songs ... At Christmas last year we struggled to get books to give to the children . . . At Christmas and Easter we look really drab as we have nothing to use for wall displays as they don't have them in Gaelic. (Practitioner, City Nursery)

We have a PC at playgroup but don't use it because we have nothing Gaelic on it and no DVDs. . . . Now there is a Gaelic TV channel with children's programmes, but we don't have an internet connection. Surely DVDs of these could be made available? (GM playgroup provider)

Computer facilities aren't very good and the lack of computer games is regrettable. (Practitioner, Small Town Nursery)

The practice of staff translating English language resources, particularly books, into Gaelic and then sticking the translation on top of the English words is widespread and time-consuming. In addition, practitioners feel obliged to produce materials for parents to use at home with their children or translations of the songs and stories which the children are learning with obvious implications for their workload. Finding ways of pooling resources and increasing the supply of commercially produced materials is an urgent requirement if children attending Gaelic medium provision are to enjoy the same rich resourcing as their English medium peers. In addition to concerns about accessibility and affordability there are questions about the appropriateness of relying on a corpus of stories, songs and poetry largely translated from English, about the appropriateness of some of these translations and the lack of attention paid to Gaelic cultural traditions.

\section{The home language learning experience}

The number of children learning Gaelic at home is decreasing as a result of the failure of intergenerational language transmission. Consequently, as more GM preschool and primary provision becomes available, particularly in areas where Gaelic in not widely spoken, the number of settings where only one or two children, or none at all, speak Gaelic at home is growing. Our survey data suggests that in the vast majority of settings ( $88 \%$ ) very few children speak Gaelic at home while in the remainder only about half of the children come from Gaelic speaking families.

Only one child in the group has a Gaelic speaking parent. (Practitioner, Small Town Nursery)

Families have mixed language backgrounds - a small proportion of parents are native Gaelic speakers, the largest proportion of families have one parent who speaks Gaelic, others have a grandparent who speaks Gaelic, others have no Gaelic at home. (Head, City Nursery)

Two set of challenges arise from these circumstances. One set of issues is around the limited opportunities that children in Gaelic medium settings have to hear and 
use the target language (Macrory, 2006): for most children their only opportunity to learn Gaelic is in their preschool setting. While the recent advent of a (part-time) Gaelic television channel is making a difference to the 'quantity' of Gaelic that children can be exposed to, most of their opportunities to communicate actively in their second language are in the very particular context of a preschool playroom: an environment set aside for young children with consequently limited vocabulary and genre and a prescribed range of relationships. This means that providers need to adopt an overt language development strategy to ensure that children acquire competence in Gaelic, as this is unlikely to happen 'naturally' - as might be possible if only a few of the children were not from Gaelic-speaking homes. However, our evidence suggests that most providers have not had the kind of training that would allow them to formulate and refine an evidence-based language acquisition strategy that can work in tandem with the early years curriculum.

The second set of challenges arises from the reasons why parents choose Gaelic medium preschool provision and their expectations for their children's language development. Our research indicates that there is considerable variation in parents' motives for enrolling their children in Gaelic medium provision. Most of the parents we talked to in the course of the study were enthusiastic supporters of Gaelic medium education. In some cases this was because they were committed to the revitalisation of Gaelic for personal or family reasons. For instance, when a grandparent spoke Gaelic some parents wanted to ensure that the language they had not learned was passed on to the next generation. Others had chosen this provision because they were keen for their children to benefit from an early opportunity to become bilingual.

We don't speak Gaelic at home, and I haven't sent any of my older children to the Gaelic medium [primary] unit, but they have all been to this [Gaelic-medium] nursery and I know that when they have to learn other languages later on at school, they'll find it really easy. . . . When they're young, they just soak it all up like sponges. (Parent 1, Island)

In other cases, their choices are made for reasons largely unconnected to language learning, but rather by what they identified as social or educational advantages offered by GM provision.

This is a unique, small-scale, attentive environment. (Parent 3, Small Town)

The Gaelic-medium groups are nice groups - the people who have made that decision are a certain kind of people. There is a whole social thing. (Parent 4, Small Town)

This variation in reasons for choosing Gaelic medium provision and parents' differing understandings of what it takes to become a fluent speaker of a second language make it difficult for providers to engage families in supporting their child's linguistic development in ways that are likely to have the greatest impact. Some providers ask parents to help their children to learn Gaelic by undertaking certain activities at home and some practitioners invest considerable amounts of time to develop resources for this. 
[We] send home vocabulary - in Gaelic, phonetically and in English. . . [We] have a Gaelic lending library for children and Play Along Maths sacks in Gaelic and English. These are really popular. (Head, City Nursery)

[We] offer a CD of games and songs in Gaelic [to parents] (Practitioner, Small Town Nursery)

Where parents do not speak Gaelic at all it is difficult to know how they can support their children's acquisition of the language. Language classes for parents are available in collaboration with some settings and, in some areas, there are community classes for Gaelic learners, some specifically targeted at the parents of young children. But while the families we interviewed at our case study settings were keen to support their children's development at this stage this seldom went beyond the acquisition of specific phrases or songs from the vocabulary lists and copies of lyrics shared with parents. Some providers would like to make it a requirement that parents of children in Gaelic medium education commit themselves to learning the language, so that they can support their children's learning, but it is clear that some parents would be unable to make this commitment. Other providers, keen to encourage recruitment, are at pains to point out that lack of Gaelic at home should not discourage parents from enrolling their child in GM preschool. In these circumstances the Gaelic medium preschool playroom becomes the only environment in which a child can both learn Gaelic and have opportunities to use this new second language.

\section{Pedagogic challenges}

As mentioned above, preschool practitioners working in Gaelic medium provision are unlikely to have had any specific language learning training, either in their initial or continuing professional education. Most practitioners will have been recruited because they have suitable early years qualifications (gained in English) and also speak Gaelic, although finding suitably qualified Gaelic speaking staff had been a problem for over three quarters of our survey respondents. While qualified early years practitioners can be expected to be aware of children's need for appropriate support to develop their language and communication competencies their training does not prepare them to facilitate second language learning. The remote and scattered locations of much of the Gaelic medium provision offered outside the central urban belt further compounds the situation as opportunities for informal learning from other practitioners and the sharing of effective practices are limited by geographical location.

As well as rising to the challenges of assisting young children to learn a second language (and one which they usually only encounter in the playroom) practitioners have to plan to meet two different sets of curriculum expectations (for Gaelic learners and Gaelic 'native' speakers, Learning and Teaching Scotland, 2009). The focus of the curriculum expectations for Gaelic learners is on experimenting and exploring the use of their new language but they are also expected to have access to the same breadth and richness of curricular experiences as children learning through the medium of English. But it can be argued that in order to have access to 
all areas of the curriculum in preschool and in early primary school children need a degree of fluency with the language of the educational setting that goes beyond exploration and the use of familiar and routine words and phrases. For example, working with quantities, shapes and classifications requires conceptual development and specific vocabulary. In one setting we observed a practitioner and child building words with plastic letters. The contextual conversation was in Gaelic but the words spelled out were names and English words, reflecting the vocabulary most familiar and meaningful to the child. The important contribution that role play makes to children's development (Rogers and Evans, 2008) can be compromised if children feel unable to use the language with which they are most familiar (English for the majority) when they are in a GM playroom. Conversely, the opportunity offered by imaginative play to use Gaelic in meaningful interactions with peers is missed if children lack an appropriate level of fluency.

Gaelic medium provision can become an arena for conflict between two different pedagogical approaches. The evidence from our case study settings, key informant interviews and survey suggests that there is a tension between those who focus on supporting children's language learning and others for whom access to all curricular areas (as defined in the Curriculum Framework for children 3 to 5 ) is the key indicator of quality.

The authority is aware that they need to develop the curriculum - add richness and breadth. We have real concerns in the authority that the Gaelic providers have a different focus. . . [I] [h] ave heard staff say that they are there to teach children Gaelic but . . . they are paid to deliver the curriculum.

(Local authority quality improvement officer)

Our respondents tended to talk of the curriculum and language learning as distinct educational practices, as layers which can be given greater or lesser priority. This tension is exacerbated by the differences in the underlying approaches apparent in early years pedagogy and language learning pedagogy. Allowing children to make individual choices from an array of activities offered and supporting learning through engaging in play, dialogue and questioning are important characteristics of the early years pedagogy in Scotland which contrast with the more 'teacherly' and adultdirected interactions typically employed by language teachers.

In some respects it isn't really possible to enforce a totally Gaelic environment. For example, 'free play' is a designated activity and by definition the children have to do this on their own to a considerable extent. (Practitioner, City)

Supporting 3-5-year olds to acquire a level of confidence and competence in a second language that gives them access to all aspects of the curriculum, while adhering to the key pedagogic principles of early years educators requires the development of specific practices that go beyond the current listing of key words to be acquired in each term or routine phrases involved in care and social interactions. While there is no doubt that supporting the language learning of young children requires appropriate pedagogy and resources there will always be some inherent tension between priorities unless there is a more developed understanding of 
curriculum and pedagogy for Gaelic medium preschool provision in particular. There is a need for the community of Gaelic medium practitioners to work together to articulate an understanding of the curriculum for children in the Early Level (from 3 to 6 years old) that makes sense in their contexts and to develop pedagogical approaches that meet the needs of children learning through the medium of a language they are in the process of acquiring, as well as others who come to the setting as fluent Gaelic speakers. The development of a policy on Irish medium immersion education (SGIP, 2009) offers a model which education policymakers and language organisations in Scotland could build on to achieve an appropriately targeted position on the goals and methods for Gaelic medium preschool education.

\section{Conclusions}

In this paper we have outlined the challenges which practitioners experience as they work to support preschool children's acquisition of Gaelic as a second language and their physical, social and emotional and cognitive development. Following the review in Scotland, decisions made by Bòrd na Gàidhlig to become more directly involved in attending to the training and resource needs of GM preschool providers, through the development of a training programme and new working partnerships, will go some way to meeting the concerns revealed in the survey about structural features of provision and some aspects of practice development, though the impact of these innovations is a matter for later evaluation.

Our evidence makes it clear that if practice is to be developed then there need to be increased opportunities for staff to learn from each other, training targeted specifically at the current needs of practitioners working in Gaelic medium settings, an ample supply of Gaelic medium resources and the creation of richer language learning environments. However, lying behind these changes is the more challenging task of re-conceptualising the curriculum and developing appropriate pedagogy for Gaelic medium settings. This is an essential development for any minority language provision, not just for Scotland, if the children attending are to experience the same support for development that their peers in majority language settings receive, as well as the additional benefits conferred by bi-lingualism. As the observations described above make clear, it is not enough to talk to children in another language or translate stories and songs into the minority tongue. The balance of priorities in the curriculum, expectations for progress and the nature of effective pedagogic interactions and relationships all have to be re-considered for the specific circumstances that the children are experiencing. There is a need for further empirical study and for the sharing of experiences between language communities. There is no 'blue-print' for preschool provision for children acquiring a minority language in any cultural or linguistic context and the provision of development workers or materials will not in itself ensure effective language learning and high quality experiences. Targeted research is needed to explore, for instance, the affective aspects of learning in another language or the ways in which children communicate and learn with peers. But political support is necessary too to make the adjustments that will allow minority language provision and bi-lingual preschool education to deliver all that is expected of it.

\section{References}


Baker, C. 2006. Foundations of Bilingual Education and Bilingualism ( $4^{\text {th }}$ Edition). Bristol: Multilingual Matters.

Bòrd na Gàidhlig 2007(a) National Plan for Gaelic.

http://www.bord-na-gaidhlig.org.uk/national-plan-for-gaelic.html accessed 22.12.10.

Bòrd na Gàidhlig 2007(b) National Gaelic Education Strategy - Annex A National Plan for Gaelic.

http://www.bord-na-gaidhlig.org.uk/national-plan-for-gaelic.html accessed 22.12.10.

Goelman H., Forer, B., Kershaw, P., Doherty, G., Lero, D. and LaGrange 2006. Towards a predictive model of quality in Canadian child care centers. Early Childhood Research Quarterly 21: 280-295.

Harms, T., Clifford, M. and Cryer, D. (2004) Early Childhood Environment Rating Scale revised edition (ECERS- $R$ ). Boston, MA: Teachers College Press.

Hickey, T. and Lewis, W.G. 2009. Exploring policy and practice in Welsh-medium preschools with children from different language backgrounds. Paper given at Language Policy and Language Learning: New Paradigms, and New Challenges Conference, University of Limerick (18-20 June).

Howard, E. R., Sugarman, J., Christian, D., Lindholm-Leary, K. J., \& Rogers, D. (2007). Guiding Principles for Dual Language Education (2nd Edition). Washington, DC: Center for Applied Linguistics.

Johnson R.K. and Swain M. 1997. Immersion Education: International Perspectives. Cambridge: Cambridge University Press.

Learning and Teaching Scotland. 2009. Curriculum for Excellence: Gaelic (learners) experiences and outcomes.

http://www.Itscotland.org.uk/curriculumforexcellence/languages/gaeliclearners/index. asp accessed 19.10.09.

Learning and Teaching Scotland. 2009. Curriculum for Excellence: literacy and Gàidhlig experiences and outcomes.

http://www.Itscotland.org.uk/curriculumforexcellence/languages/literacyandgaidhlig/in dex.asp accessed 29.10.09

Macrory, G. 2006. Bilingual language development: what do early years practitioners need to know? Early Years 26, no 2: 159-169.

Mhic Mhathúna, M. 1999. Early Steps in Bilingualism: Learning Irish in Irish Language Immersion Pre-Schools. Early Years 19, no 2: 38-50.

Mhic Mhathúna, M. 2008. Supporting children's participation in second-language stories in an Irish-language preschool. Early Years 28, no 3: 299-309. 
Mhic Mhathúna, M. and Mac Con lomaire, M. forthcoming, Developing a Pilot Scheme for Language Planning in Gaeltacht Naionrai. An Leanbh Ó, Journal of OMEP Ireland.

National Institute of Child Health and Human Development (NICHD) Early Child Care Research Network. 2005. Early Child Care and Children's Development in the Primary Grades: Follow-Up Results from the NICHD Study of Early Child Care. American Educational Research Journal 42, no 3: 537-570.

Peisner-Feinberg, E.S. and Burchinal, M. R. 1997. Relations between preschool children's childcare experiences and concurrent development: The Cost, Quality and Outcomes Study. Merrill-Palmer Quarterly 43, no 3: 451-477.

Phillipsen L.C., Burchinal M.R., Howes C. and Cryer D. 1997. The Prediction of Process Quality from Structural Features of Child Care, Early Childhood Research Quarterly 12: 281-303.

Rogers, S. and Evans, J. 2008. Inside role-Play in Early Childhood Education. Abingdon: Routledge.

Sammons, P., Elliot, K., Sylva, K., Melhuish, E., Siraj-Blatchford I. and Taggart B. 2004. The impact of pre-school on young children's cognitive attainments at entry to reception. British Educational Research Journal 30, no 5: 691-712.

Scottish Executive 2004 A Curriculum for Excellence http://www.scotland.gov.uk/Publications/2004/11/20178/45862 accessed 19.10.09.

Scottish Executive Education Department (SEED) 2007. Growing up in Scotland: A study following the lives of Scotland's children.

http://www.scotland.gov.uk/Publications/2007/01/17162004/15 accessed 29.10.09.

Scottish Parliament (2005) The Gaelic Language (Scotland) Act.

http://www.legislation.gov.uk/asp/2005/7/contents accessed 22.12.10

Stephen, C., McPake, J., McLeod, W., Pollock, I. and Carroll, T. (2010) Review of Gaelic Medium Early Education and Childcare. Edinburgh: Scottish Government Social Research. http://www.scotland.gov.uk/Publications/2010/06/22090128/14 accessed 22.12.10. 